\title{
NORWID AND THE EXILES TO SIBERIA
}

Do czasu jedni pościć będą pieśnią, Drudzy zamarzą się i w mgły roześnią, Inni utoną w śmierci oceanie;

Ci w Sybir pójdą - owi na wygnanie [...].

(Niewola [Captivity], PWsz, III, 375)

For a time, some will be fasting on the song,

Others will be dreaming and will dream away in the fog,

Others will drown in the ocean of death,

Some will go to Siberia - others to exile [...].

Wielu zginęło - wielu w Syberii? - i wielu ich pomni i modli się za nich?

(List do Mariana Sokołowskiego [Letter to Marian Sokołowski], PWsz, IX, 139-141)

Many have died - many in Siberia? - and many remember and pray for them?

[...] w stronę jedną sybirskie powózki,

W drugą pielgrzymi-kostur... oto - są posągi

Tych epok, jak się one nastawiały ongi.

(Rzecz o wolności stowa [On the Freedom of Speech], PWsz, III, 606)

[...] one way - Siberian carriages

The other way - the pilgrim's cane... these are the monuments

Of these epochs, as they once erected themselves.

The Siberian theme is, undoubtedly, one of the most important themes within the Russia-related issues found in Norwid's works, in line with its place and significance in Polish history, literature and iconography of the Romantic era. At the 
same time, it is one of the most ample, multidimensional, and ambiguous themes; it is thought-provoking and still far from being exhaustively studied. The semantic space of this subject is situated in Pisma Wszystkie [Collected Writings] on the border between historiosophy and politics, literature and individual biographies, ethics and law-making, martyrology and eschatology, as well as at the intersection of national and "supranational" questions.

Norwid's Siberia has already found multiple commentators, such as, first and foremost, a prominent expert in Siberian themes of the Romantic era - Zofia Trojanowiczowa, followed by Zdzisław Łapiński, Edward Kasperski, Waldemar Smaszcz, Aniela Kowalska, Mieczysław Porębski, and recently Włodzimierz Torun (who produced a systematic and thematic synthesis of these themes in Norwid's works) and Ewangelina Skalińska. ${ }^{1}$

The previous research clearly shows that it was more natural for the poet to interpret Siberia in terms of symbolic and metaphorical categories, rather than geographical and topographical, which results mostly from the fact he (luckily) did not know this reality from his own experience, as well as from Norwid's tendency to make the universal and parabolic out of what is individual, concrete, and temporal. The Siberian experience permeates the fabric of Norwid's writings as a generational experience and a national trauma, becoming the most salient martyrological symbol. ${ }^{2}$

1 Cf. Z. Trojanowiczowa, Sybir romantyków, Kraków 1992; Z. ŁaPIŃski, Norwid, Kraków 1984; E. KASPERSKI, Wokót „, Syberii” Norwida. Dwa modele etyki, historiozofii i patriotyzmu, [in:] Kresy, Syberia i literatura. Doświadczenie dialogu i uniwersalizmu, eds. E. Czaplejewicz, E. Kasperski, Warszawa 1995, pp. 153-172; IDEM, Dyskursy romantyków. Norwid i inni, Warszawa 2003; W. Smaszcz, Trzy analizy (,,Noc,” „Legenda,”, Syberie”), „Poezja” 1983, Vols. 4-5, pp. 170-183; A. Kowalska, Wiersze Cypriana Norwida, Warszawa 1983; M. PoRĘBSKI, Sybirskie futro wziąt [in:] Ikonografia romantyczna. Materiaty sympozjum Komitetu Nauk o Sztuce Polskiej akademii Nauk, Nieborów 26-28 June 1975, ed. M. Poprzęcka, Warszawa 1977, pp. 13-31; W. ToRuŃ, Syberia w twórczości Cypriana Norwida, [in:] Zesłańcy postyczniowi w Imperium Rosyjskim. Studia dedykowane profesor Wiktorii Śliwowskiej, ed. E. Niebelski, Lublin- Warszawa 2008, pp. 373-384; W. Toruń, Norwid o niepodległej, Lublin 2013, pp. 125-138; E. SkALIŃSKA, „, Dwie Syberie” - Norwid i Dostojewski o losach zesłańców polskich, [in:] IDEM, Norwid - Dostojewski Między diachronia a synchronia odniesień, Warszawa 2012, pp. 247-254. On Siberian exiles see: M. JANIK, Dzieje Polaków na Syberii, Kraków 1928; A. Brus, B. KaCZYŃSKa, W. ŚlıwowsKa, Zesłanie i katorga na Syberii w dziejach Polaków, Warszawa 1992; W. ŚLIwowska, Zestańcy polscy w Imperium rosyjskim w pierwszej połowie XIX wieku: słownik biograficzny, Warszawa 1998; B. JĘDRYCHOwsKA, Polscy zesłańcy na Syberii 1830-1883, Wrocław 2000; J. Trynkowski, Polski Sybir. Zestańcy i ich życie. Narodziny mitu, ed. W. ŚLIwowsKA, Warszawa 2017; Migration and Mobility in the Modern Age: Refugees, Travelers, and Traffickers in Europe and Eurasia, eds. A. Walke, J. Musekamp, N. Svobodny, Bloomington 2016.

2 Zofia Trojanowiczowa wrote: "The experience of Siberia had the character of a collective experience encompassing also those who avoided being exiled. It was perceived as the experience 
Exiles to Siberia had already profoundly affected Norwid's youthful consciousness in his middle-school years (i.e. in the 1830s) as the next wave (following the one after the failure of the November Uprising) began at that time. In 1838, a conspiracy was revealed and the Polish People Association was brought down in Warsaw. Michał Olszewski, Hipolit Krzywicki, and 21-year-old Gustaw Ehrenberg (whom Norwid knew personally), ${ }^{3}$ among others, were arrested and exiled to Siberia. The first two never returned to the country; whereas Ehrenberg returned only after 18 years. ${ }^{4}$ One year later (in 1839), a public execution of Szymon Konarski was conducted in Vilnius. ${ }^{5}$

In June 1839, 18-year-old Cyprian witnessed the exile of members of a conspiratory organisation "Świętokrzyżowcy" [Holy Cross Fighters] imprisoned in the Warsaw Citadel. He realised that this tragic event almost coincided with the publication of the Paris edition of Juliusz Słowacki's Anhelli (in 1838). ${ }^{6}$ The spectre of Siberia eventually threatened Norwid himself when he was questioned, pressurised, and blackmailed in the Berlin prison" by Feliks Fonton, "reprezentant

of the whole nation. [...] Siberia imposed its presence on the collective imagination as a basic component of the national bond, as a permanent and unalterable symbol of the tragedy of contemporary history. Dangerous, remote and alien, it called for being tamed, managed, and emotionally and intellectually comprehended.” Z. Trojanowiczowa, Sybir romantyków, pp. 82, 90.

3 Cf. Z. Trojanowiczowa, Z. DAmbek, Kalendarz życia i twórczości Cypriana Norwida, Vol. I: 1821-1860, Poznań 2007, p. 31. Norwid mentions this "wieszcz" [prophet] and "wajdelota" [bard] in the article Z pamiętnika [O zemście] [From a diary \{On revenge $\}$ ] (PWsz, VII, 42).

4 He first worked in Nerchinsk mines and subsequently, after being relieved from katorga [forced labour] in 1854 he was directed to settle in the Ural region. He returned to the country in 1848, a changed and broken man.

5 The poet saw this death as a "meteor" casting its rays as far as to Siberia (Z pamiętnika [O zemście] [From a diary \{On revenge\}] PWsz, VII, 40).

6 “ [...] w Warszawie 183[9] r. nocą budzeni bywaliśmy przez kolegów, aby choć obecnością naszą zasłać pożegnanie wysyłanym na Sybir, Słowacki wtedy z drugiego końca Europy Anhellego ojczyźnie przysyłał [...]. Tej samej zaś zimy w zacnym polskim salonie mówiła mi pewna pani domu, ,że rozpowiadają coś ciągle o zsyłkach, a przecież z nas nikogo w czwartek nigdy nie brakuje" (PWsz, VI, 463).

"[...] in Warsaw in 183[9] we would be woken by friends in order to at least be present and bid farewell to those sent to Siberia. At that time Słowacki was sending Anhelli from the other end of Europe to the homeland [...]. And in the same winter, I was told by a hostess in a respectable Polish salon that "they keep talking about sending people to exile, but somehow no one is ever missing here on Thursdays."

7 The threat of turning Norwid in to the Russians was very real. He mentioned it after many years (in 1880) in his letter to Konstancja Górska: “jedną książkę pozwolili mi Prusacy mieć w więzieniu, i zażądałem Danta, i dali - thumaczyłem więc Inferno [...] - gdy mnie miano wydać Rządowi Mikołaja I-o - i zapewne, gdyby wydali, tłumaczyłbym Danta gdzie indziej” [the Prus- 
Państwa Rosyjskiego" [the representative of the Russian state] (PWsz VIII, 151) who - as it was written by Zygmunt Krasiński in a letter to Delfina Potocka "made use of the courtesy of the Prussian police to put him there." 8

The theme of exile and martyrdom was - as it is manifested in preserved notes and letters - often taken up by young Norwid in conversations with his friends and acquaintances, such as Zygmunt Krasiński and Henryk Moraczewski. The former is known from the correspondence between Krasiński and Delfina Potocka (cf. Z. Krasiński's letter to D. Potocka, Rome 1848, PWsz XI, 462-463). The latter is documented in a part of the Moraczewscy family's album entitled [ $Z$ ] rozmowy $z$ Norwidem, where a member of the family transcribed (rather chaotically) their impressions after the meeting with the poet. ${ }^{9}$

Unsurprisingly, Siberia affects different areas of the poet's reflection, encroaching even upon Norwid's metaphoric language. It is ubiquitous (not in the number of references, but in the sense of its semantic scope) in his works in different contexts, even in rather unexpected ones (e.g. in Promethidion, in the poem Wielkość [Greatness]), not always, however, explicitly, not everywhere expressis verbis. It gains the status of a topos. ${ }^{10}$

sians let me have just one book with me in prison, so I requested Dante and they gave it to me. So, I was translating Inferno (...). When I was to be handed over to the Nicholas I's officials - and surely if I actually had been handed over, I would have been translating Dante elsewhere] [i.e. not only in a prison inferno, but also the Siberian one - R.G.-S.] (PWsz, X, 142).

Count Włodzimierz Łubieński, Norwid’s friend, who "co sobota przychodził pod okno więzienne" [would come to the prison window every Saturday] (PWsz, X, 142), wrote in a letter to his mother: "In the 7 days that he spent in this harsh prison, under constant uncertainty about whether or not he would be sent to Russia any time, Norwid made a souvenir for me, a sort of a prayer book [...]." Cit. after: Z. MuszyŃSKa [TRojAnowiczowa], Norwid w więzieniu berlińskim, "Pamiętnik Literacki" 1961, Vol. 1, p. 195.

8 List Zygmunta Krasińskiego do Delfiny Potockiej, Rzym 25-26 stycznia 1848, [in:] Z. KrAsiński, Listy do Delfiny Potockiej, ed. Z. Sudolski, Warszawa 1975, Vol. III, p. 605.

9 Cf. Z. Trojanowiczowa, Z. Dambek, Kalendarz życia i twórczości, Vol. I, p. 105.

10 Cf. Z. Trojanowiczowa, Sybir romantyków, p. 140. The poet made the Siberian exile an ample metaphor of the fate of the whole emigration (in his Parisian exegesis of Anhelli). Jakub Gordon also placed an equal sign between the sybiraks and emigration: "One of the strangest twists of providence is, undoubtedly, this almost mythical scattering of the sons of Poland in the two opposing ends of the world: the Siberia and the West. Exiles and wanderers, sybiraks and refugees, how different are the fates of the same misfortune! Forced labourers, political exiles and soldiers have lost their freedom, their fatherland, and everything else apart from a slim hope for living into the old age, a sentimental hope at the mercy of the enemy. Refugees have evaded the vengeance of the Tzar and scattered across foreign lands - seemingly free, but homeless and poor, deprived of the most valuable human right - the right to breathe one's homeland's air." (J. GoRDON, Soldat, czyli sześć lat w Orenburgu i Uralsku: nowe pamiętniki Jakuba Gordona. Leipzig 1862², pp. 215-216). 
Despite the evident and intellectually impressive examples of extending and deepening meanings, the Siberian theme was never a purely abstract or theoretical subject of artistic processing for the author of Vade-mecum. Instead, it was a problem entering the very centre and essence of the "human thing" - so important and even symptomatic in Norwid's works. It was not only mythical, metaphorical, and symbolic, but it brought to mind the faces of individual people who remained in Russia forever or miraculously returned to the land of the living. The poet, whether still in the country or later in emigration, had contact with many exiles. This fact was brought to attention by a pioneer in Siberia-related literature study - Zofia Trojanowiczowa:

The end of 1850 s saw a mass, post-amnesty return of exiles, many of whom ended up in emigration after the failure of the January Uprising. So many of them appeared then within the circle of Norwid's interlocutors and correspondents! $!^{11}$

The returned exiles, their accounts and their dramatic reactions were the first opportunity for the author of the lyric poem Syberie [Siberias] to come into direct contact with the reality of exile. It seems worthwhile to emphasise this primary aspect - i.e. this individual and personal perspective - in Norwid's reading of Siberia even before discovering its deep, hidden and polemical meanings.

Among the sybiraks there were, obviously, mostly great national heroes, widely-recognised and respected people, such as Piotr Wysocki, who was almost killed in Siberia, and Stanisław Zamojski, the owner of the palace where General Fiodor Berg's attempted assassination took place in 1863. Norwid mentioned the latter in 1861 when he was imprisoned in Warsaw together with Ksawery Norwid (PWsz VIII, 451-452). ${ }^{12}$ But even some of the poet's relatives were sentenced to be deported to the East.

In his correspondence, however, Norwid revised the myth of Siberia, demythologised it and violated its coherence. Cf. Z. Trojanowiczowa, Sybir romantyków, pp. 140-141. The author emphasised the fact that polemical arguments against the martyrological Siberian myth appear in Norwid's correspondence only in his letters to several individuals (mostly to B. Zalewski), but never in his poetry. It may be due to Norwid's taking particular care not to be misunderstood and, consequently, not to harm the feelings of the exiled and their families.

11 Ibid., p. 138.

12 Norwid added the Siberian legend to General Henryk Dembiński, depicted in a famous painting by Henryk Rodakowski:

"Sybirskie-futro wziął i ręką waży leniwą,

Acz mu należy się, więzień i wygnań królowi!"

(Na portret generała Dembińskiego [The Portrait of General Dembiński], PWsz I, 253). 
Józef Hornowski (the son of a "million" uncle Hornowski) was deported to Siberia after the January Uprising. He had studied in Paris to become an engineer and later lived on the land property in Łochów. ${ }^{13}$ It is possible that it was this harsh experience of deportation that led to his nervous breakdown and mental illness leading to several years in a mental institution, ${ }^{14}$ as mentioned in the diaries of his wife - Łucja Hornowska née Dunin-Borkowska. ${ }^{15}$

The Siberian tragedy unfolded also in a more distant branch of the Norwid family. In 1858 the poet was asking his cousin Michał Kleczkowski:

Kto jest Ci ten Kleczkowski na Litwie, który był na Syberii - którego majątek skonfiskowany? - z nich są na Litwie możni panowie Kleczkowscy - ja ich nie znam, ale znam ich bliskich (Letter to M. Kleczkowski, PWsz VIII, 342).

Who is this Kleczkowski in Lithuania, who was in Siberia - the one whose property was confiscated? - he is one of the wealthy Kleczkowki landlords in Lithuania - I do not know them, but I know their relatives.

This Siberian story of Kleczkowski from Lithuania (at least one of them bearing this name), which intrigued Norwid so much, ended up surprisingly well. In 1870 the poet already informed Michał that the family of the previously exiled man successfully deals in the production of stock cubes from " $z$ bydła i dzikich zwierząt licznych w tych okolicach" [beef and locally plentiful wild game] (Letter to M. Kleczkowski, PWsz IX, 458), whose label he even attached to the letter. ${ }^{16}$

"The Siberian fur he took and is weighing it with a lazy hand,

He deserves it well, the king of prisoners and exiles!"

13 Insurgent fighting also took place in Łochów, which is mentioned by Norwid in his letter to M. Kleczkowski (PWsz IX, 83).

14 "The most tragic was the life of Łucja's husband. He suffered a nervous breakdown and subsequently a mental illness and was institutionalised in a mental hospital where he spent several years. He died in 1898 and was buried in Lviv." Z pamiętnika "Kusicielki." "Gazeta Lochowska" 79(111) April 2004.

15 Cf. Ł. Hornowska, Wspomnienia, ms. BN no. 10423, Parts II, III; Z. TrojanowiczoWA, E. LijewsKa, Kalendarz życia i twórczości Cypriana Norwida, Vol. II: 1861-1883, Poznań 2007 , p. 84.

16 The stock cubes which, incidentally, were sold on the Polish territory as well as abroad and were even exhibited at 1873 Vienna World's Fair. (cf. "Biblioteka Warszawska" 4(1873), Vol. 11, May 1873). Agaton Giller who was present at the event wrote in his letters reporting from the Vienna World's Fair (from 19 June 1873):

“[...] the way of making stock cubes developed by Władysław Kleczkowski from Lithuania is gaining publicity. He makes it from wildfowl and northern animals in Pineda, Arkhangelsk Governorate, as well as two other manufacturing plants that he set up: in Ulsztym upon the Peczora River 
Władysław Kleczkowski (born about 1831) belonged to the Lithuanian Youth Fraternity $^{17}$ - a conspiratorial organisation founded in the Vilnius University in 1846 by the Dalewski brothers: Aleksander (born in 1827) and Franciszek (born in 1825). Together with them, he was imprisoned and sentenced to 10 years of harsh

and in Vologda. It is more nutritious than Liebig's meat extract, can be preserved longer, and you can dissolve the cubes in water just as quickly as this extract. In a Moscow restaurant which, by the way, is run at the Fair by a German speculator, I tried Mr. Kleczkowski's stock. It was delicious and none other, not even Ukrainian bouillon, can be compared to it. The Tzar, visiting the exhibition, asked about the production of this stock and was surprised that it was not taken on the expedition to Khiva. Mr. Kleczkowski was awarded medals at two Moscow fairs; medical department in Petersburg and a convention of physicians and naturalists in Kraków stated that the production of his stock cubes is exquisite and complies with health requirements.

Mr. Władysław Kleczkowski, of Lithuanian descent, was sent, for political reasons, to forced labour to Siberia in 1850. After his release, he was sent there again and then discovered a way to produce stock cubes from wild animals hunted by Ostyaks and Samoyedic peoples. Today he is a great manufacturer and sells his bouillon across Moscov, Poland and other countries" (Polska na Wystawie Powszechnej w Wiedniu 1873 r.: listy Agatona Gillera, Lviv 1873, pp. 27-28).

Norwid's Poezje published by Bockhouse as part of Polish Writers' Library series was also to be found at Vienna World's Fair. This juxtaposition of the best-selling Kleczkowski's stock cubes with misunderstood and unprofitable poetry of the Parisian recluse is quite telling. Notably, writing about Kleczkowski's stock production Norwid made an ironic statement about his cousin and his family's practical and down-to-earth attitude: "Idea wprowadzona w czyn na krawędzi/granicy Tartarii (barbarii) sprawiła, że pomyślałem o waszej skłonności do realizmu, którą eksponujecie $\mathrm{z}$ takim znawstwem" [The idea put in practice on the border of Tartary (barbaric land) made me think about your inclination towards realism which you expose so expertly" (PWsz, IX, 458).

The famous Kleczkowski's stock was also recognised at Warsaw Hygienic Exhibition (cf. Lista nagrodzonych na wystawie higienicznej. "Gazeta Warszawska" 15 July 1887, p. 2); cf. also: W. KLECZKowsKi, Bouillon et l'extrait le viande regardés comme conserves, du côté économique, par, Paris 1878; IDEM, Bulion mięsny w tabliczkach wyrobu, Warszawa 1871; IDEM, Bulion i extrakt mięsny jako konserwy z ekonomicznego stanowiska uważane, Warszawa 1879.

17 "It was a Fraternity of the Polish youth in Vilnius, whose goal was to boost patriotism in the general public and to prepare a national uprising in 1850 in the Vilnius Region. It was also called Lithuanian Youth Fraternity or simply the Dalewski Brothers' Plot. According to Michał Janik, the Fraternity «constantly remained in contact with the Patriotic Union in Warsaw. Its denunciation led to severe sentences." The conspirators were accused of intending to overthrow the Tsardom and arrested in May 1848. They were imprisoned in the Vilnius prison, sentenced to forced labour and sent to Siberia in 1849. [...]

The convicts were traveling on foot - in stages, chained together with criminals. [...] This humiliating and exhausting journey in cold weather, with no food or any sanitary measures, lasted, according to Wspomnienia ..., eleven months; according to quoted source texts - eight months - it started at the end of November and ended at the end of July 1851." (M. RADOMSKA, Franciszek Dyonizy Cywiński - członek Spisku Braci Dalewskich w Wilnie i jego potomni, http://zeslaniec.pl/38/ Radomska.pdf [accessed: 20 August 2017]). 
labour in Eastern Siberia. ${ }^{18}$ Władysław was one of the very few who managed to change the standard of the tragic exile's fate. By virtue of a coronation manifesto of 1856, he returned to Vilnius (in 1857) and, inspired by eating habits of the indigenous Siberian people, he became a high-earning expert in "food hygiene." His publications were even recommended by the Warsaw Medical Association.

Some of the Kleczkowki sybiraks were less lucky, however. Maurycy Kleczkowski, a former January Uprising insurgent, returned to the country with Bronisław Zalewski. His brother, Jan, was not so fortunate and died in Siberia in $1869 .{ }^{19}$ Kazimierz Kleczkowski, a January Uprising insurgent from Narbutt's unit, was also a sybirak and was sent to the Penza Governorate at the age of $29 .{ }^{20}$

The Siberian experience also marked the life of Ludwik Norwid's father-in-law Konstanty Jarnowski, a participant of the November Night (pardoned in 1841):

Prof. Jarnowski jest wprawdzie ojcem mojej bratowej, - pisał Norwid do Józefa Bohdana Zaleskiego w 1858 r. $-[\ldots]$ p. Jarnowski należy do liczby Belwederczyków i w k a j d a n a ch był na Syberi i, co ja wiem, bo byłem wtenczas w Warszawie (PWsz VIII, 353).

Prof. Jarnowski is, in fact, the father of my sister-in-law,-- Norwid wrote to Józef Bohdan Zaleski in $1858-[\ldots]$ Mr. Jarnowski is one of the Belweder conspirators and he was in S i beria in fetters, which I know because I was in Warsaw at that time.

Norwid was also surrounded by many friends who returned from Siberia (some of whom were even exiled twice). By the time when he was in his middle-school, Norwid made friends with a bit older Karol Baliński (nicknamed Karol from Jarosławiec), later depicted in the drawing Chata na Sybirze, [The Hut in Siberia] (1855) - a son of a legionnaire and Napoleonic era soldier, poet, publicist, postNovember activist. Nota bene, both are found in Berlin police records as members of the "Christian social party" (together with Władysław Dzwonkowski, Michał

18 Cf. J. Glaubicz-SABIŃSKi, Dziennik syberyjski. Dziewiętnaście lat wyrwanych z mojego życia, czyli dziennik mojej niewoli i wygnania od 1838 r. do 1857 r. włacznie, foreword and footnotes by J. Trynkowski, Warszawa 2009, p. 58.

19 Władysław and Jan's tomb (only symbolic in the case of the latter) is found in the old part of the Rasos Cemetery in Vilnius, Section 4 at the Hill of Writers. Cf. http://www.rossa.lt/index. php/pomniki?view=entry\&id=813 [accessed: 20 August 2017]; cf. also Katalog polskich miejsc pamięci narodowej na Litwie. Cmentarze wojskowe, groby żołnierskie, pomniki, upamiętnienia. Wersja robocza, Polish embassy in Vilnius, Vilnius 2016, http:/www.wilno.msz.gov.pl/resource /861ec31b-a7fc-453f-b263-e7925e358015:JCR [accessed: 20 August 2017].

20 Cf. Wykaz szlachty w 1863 roku więzionej, prześladowanej i zesłanej z powiatu lidzkiego guberni wileńskiej, http://genealogia.lt/pdfs/Powstancy\%201863\%20r.pdf [accessed: 20 August 2017]. 
Łempicki and Karol Rogowski), which was associated with "Krzyż i Miecz" ["Cross and Sword"] published by Baliński in Poznan. ${ }^{21}$

Baliński, a member of the Polish People Association, was initially sentenced to death but instead was deported to the south-central part of Russia to Ishim in Tyumen Oblast (located by Yekaterinburg-Tyumen-Omsk railway) ${ }^{22}$ and was released in 1842, and then again arrested in 1846. Owing to a doctor's certificate stating the risk of his impending death (due to acute heart failure), he was eventually released in April $1847 .{ }^{23}$ His Pisma (1849) dedicated to "dear brothers [...] fading away in Siberia as a proof of deep respect and undying friendship," 24 were "a faithful, although only partial, depiction of the scenes of this national tragedy and its spirit -

21 Baliński was also a collaborator of the Poznań "Goniec." Cf. also: Z. Trojanowiczowa, Z. DAmbeк, Kalendarz życia i twórczości Cypriana Norwida, Vol. 1: 1821-1860, pp. 527-528.

22 Cf. W. ToRuń, Syberia w twórczości Cypriana Norwida, p. 138.

23 Ibid., Pisma, from p. XXVI.

24 Ibid., p. IV. In this collection there are works written from the Warsaw Citadel in 1838 (and later in 1847), the famous poem Pożegnanie [Farewell] among them (ibid. p. 5):

„Gdziekolwiek wyrok carski nas zawlecze,

Oszukamy jego dumę,

Niesiemy z sobą prawa człowiecze!

Niesiemy wolności dżumę!"

"Wherever the Tsar's sentence would bring us,

We'll fool his pride,

We carry with us the human rights!

We carry the plague of freedom!"

In this volume there are also few poems written in Ishim and in Moscow, but also poetry written after the return to the country. They formed a moving literary documentation of the Siberian drama of a "wordless bard":

„Pamiętasz Sibir? tę ziemię przeklętą,

Stokroć przeklętą, choć już w niej nie gnijem,

Naszymi łzami i krwią przesiąkniętą,

Braci poległych pod moskiewskim kijem!

Pamiętasz Irkuck, gdzie Skiba spoczywa!

Miny Nerczyńska głośne polskim młotem!

Tam Piotr! tam oni! - tam wszystko nas wzywa!

Ach bracia! Wiecznie pamiętajcie o tym! - [...]

Dla mnie świat smętarzem - dla mnie szczęścia kwiecie

Na zawsze uwiędło, pobladło!

Gdzie stąpię, grób depcę - i sam na tym świecie,

Błądzę jak grobowe widziadło."

(K. BALIŃSKI, Piewca oniemiały [Wordless bard], [in:] IDEM, Pisma, p. 15) 
the tragedy which started on the banks of the Vistula and ended beyond the Volga, in the area of the Irtysh." 25

In 1845 in Mikołów at Władysław Wężyk's place (in his absence), Norwid became acquainted with a Polish recruit - Maksymilian Jatowt who managed to avoid being drafted into the army. The poet immediately helped the fugitive and gave him money, his own passport and a part of a map of Prussia cut out of the bigger whole (Teksty suplementowe [Supplement texts], PWsz XI, 456). Although this time Jatowt managed to get to Paris safely and avoid exile, he did not avoid Siberia in the future; after he returned to the country in 1848 at the age of 19 , he mindlessly and voluntarily (!) reported to the authorities. He was detained in the Warsaw $\mathrm{Citadel}^{26}$ in a cell with a symbolic, Mickiewicz's number - 44. Later, he was sent to a penal platoon in Orenburg (he served in the $23^{\text {rd }}$ infantry division) from where he eventually went to Uralsk. After the death of Nicholas I, he was granted "pardon" which resulted in him being sent to Sevastopol. Depressed at the thought that the only coming change was the change of address of his exile, he daringly escaped on his way to Crimea using a military carriage ("at the expense of the Moscow government"!). ${ }^{27}$

Jatowt left behind interesting diaries and memoirs from exile-Moscow: $J$. $G$. 's, a Pole from the Crown and Citizen of the US, Diaries ${ }^{28}$ Pictures of Tsarism: J. Gordon's Diaries ${ }^{29}$ - which describe the prison, the trial and the „forced” jour-

"Do you remember Siberia? This cursed land,

A hundred times cursed, although we do not rot there anymore,

This land soaked with our tears and blood,

Brothers perished under the Moscow stick!

Do you remember Irkutsk, where Skiba rests!

The mines of Nerchinsk are loud with Polish hammer!

There's Peter! There are they! - everything is calling us there!

Oh brothers! Always remember it! - [...]

For me, the world is a cemetery - for me, the flower of happiness

Has withered and faded forever!

Wherever I step, I step on a grave - and I am alone in this world,

I am roaming around like a graveyard spectre."

Norwid was certainly familiar with these poignant verses.

25 Cf. J. Gordon, Moskwa: pamiętniki J. G., Polaka z Korony, Obywatela Stanów Zjednoczonych Ameryki, Paris 1861.

26 IDEM, Obrazki caryzmu.

27 Cf. also E. MalinowsKa, Rosja i Rosjanie we wspomnieniach Maksymiliana Jatowta, [w:] Od oświecenia ku romantyzmowi i dalej... Autorzy - dzieła - czytelnicy, eds. M. Piechota, J. Ryba, Katowice 2004, pp. 184-199.

28 J. GoRdon, Obrazki caryzmu, p. 41. Jatowt described here his meeting with Norwid (pp. 125-126).

29 Gordon called Moscow and the Tsar country "an Asian building with a European pediment" (p. 194). 
ney to Orenburg - as well as Soldier, or Six Years in Orenburg and Uralsk: J. Gordon's New Diaries ${ }^{30}$ - memoirs from the Orenburg exile. ${ }^{31}$ The main goal of these accounts was to show the truth about the Tsarist apparatus of violence to the European audience. "I am not writing a romance novel here: my pen is dipped in consciousness and truth - with this book I am ready for the last judgement!",32 - the author claimed. ${ }^{33} \mathrm{He}$ described the condition of his spirit and his body during the exile in these telling words: "A 11 my vital functions were maintained, but I couldn't say I was alive." ${ }^{34}$

It is certain that Norwid read Jatowt's memoirs because he mentions them in a letter to Jan Koźmian from the $2^{\text {nd }}$ of December, 1866 (PWsz IX, 270). The poet must have been particularly interested in this publication as he knew its author personally (and he probably expected to find a mention of himself in Jatowt's diaries). Moreover, it was one of the first publications about Siberia published in print. Getting access to this publication was not difficult; Gordon's diaries were published in the 1860s in the Polish Writers' Library series in Leipzig (Volumes 6 and 33), in Brockhouse - the same publishing house that published Norwid's Poezje [Poems] - as well as in Paris.

Another well-known conspirator and sybirak, with whom the poet crossed his paths in Paris, was Agaton Giller. ${ }^{35} \mathrm{He}$ was arrested by Prussians during the Spring-

"My memories [...] are full of corpses, ghosts, ruins - and in my nightmares I see Muscovites attacking me and I grapple with them. Such is the fate of the Poles born under the Moscow reign.

The Siberian exile has become a sort of an element, a sort of a calling - just like suffering. There... towards the north and the east, there go our caravans, as if to their destinations. The history of the exiled is the most vivid part of the national history - it is an offering and a merit to God and to peoples, it is the crown of the national martyrdom. [...]

The eastern winds bring to our ears only a small part of the moaning. Unknown and innumerable are all the tragedies which take place day in, day out in this gloomy land of silence." (J. Gordon, Sołdat, pp. 109-110).

30 Ibid., p. 10.

31 Cf. J. Trynkowski, Agaton Giller, [in:] IDEM, Polski Sybir, pp. 211-298.

32 Cf. Muzeum X Pawilonu Cytadeli Warszawskiej, http://muzeum-niepodleglosci.pl/ xpawilon/agaton-giller/ [accessed: 29 August 2017].

33 S. Kieniewicz, Agaton Giller, [in:] Internetowy Polski Słownik Biograficzny, http://ip sb.nina.gov.pl/a/biografia/agaton-giller [accessed: 29 August 2017].

34 Cf. A. Giller, Podróż więźnia etapami do Syberii w roku 1854, Vols. I-II, Leipzig 1866 (Polish Writers's Library Vols. XLI and XLII). The "stages" (etapami) from the title correspond to prisons located on the way to Siberia.

35 Cf. J. Fiećko, Rosja, Polska i misja zesłańców. Syberyjska twórczość Agatona Gillera, Poznań 1997; J. Trynkowski, Agaton Giller i jego „,Opisanie Zabajkalskiej krainy,” „Studia Łomżyńskie" 5(1995), pp. 47-62; IDEM, Przedmurze syberyjskie Agatona Gillera, [in:] Polska 
time of the Peoples (in 1849, at the age of 18) when he tried to get to Hungary and was detained in Racibórz. After his escape from prison he went into hiding in the Poznań Region and Galicia. He was, however, detained by Austrian police and handed over to the authorities of the Congress Poland as a Russian subject. He spent one year in prison (1853), in an infamous Tenth Pavilion of the Warsaw Citadel $^{36}$ (a Tsarist high security political prison), sentenced for his escape from the country, hiding under a false name and spreading revolutionary propaganda. Finally, at the age of 23, he was sent to a penal platoon to Eastern Siberia. Only his sister bade him farewell. He made an almost 16-month journey to exile (to Shilka) entirely on foot and tied to a metal rod which was causing his hands to bleed. Initially, he served in the $14^{\text {th }}$ battalion in Szylkinski Zawod (the Nerchinsk region). He was released from forced labour in 1858 and forcefully deported to Siberia, first to Troitsko-Sevsko by Kyakhta, and then to Irkutsk. In Irkutsk he founded a Polish school and taught there. "He showed great mobility, was discovering the country and Russian literature about Siberia. Particularly, though, he sought contact with the Polish exiles and collected their accounts on the Polish independence move-

a Syberia. Spotkanie dwóch światów. Conference materials. Łódź 1-2 March 2001, Łódź 2001, pp. 201-208; IDEM, Kodeks etyczny zesłańca w świetle pism Agatona Gillera. „Studia Łomżyńskie” 14(2003), pp. 23-30; M. JARNECKI, Agaton Giller i jego wizja powstania styczniowego, https://wpa. amu.edu.pl/_data/assets/pdf_file/0006/278691/powstanie_wstp.pdf [accessed: 29 August 2017].

36 "The hubris with which the tsars occupy the Moscow throne is unparalleled in Europe; the power which they possess having under control several million submissive, slavish, and terrified people is frightening. This power, respected by peoples and monarchs, have made them think that they are God's representatives, earthly Gods - similarly to savage, medieval Hun and Mongol rulers who claimed to have been God's messengers, swords or scourges of God." (A. GILLER, Podróż więźnia etapami do Syberii, p. 154).

"If Napoleon had won and proclaimed a European civilisation and peoples' liberation from the burden of the tsars, commemorated it on the walls of Moscow, Europe would be of a different shape today; people would not fight for the last national rights violated by the monarchs united against the Great Napoleon. It if had not been for the bloody, stubborn bravery of the Muscovites, or Napoleon's pride, we would be free and would not have to follow in his footsteps to Siberia" (ibid., p. 167).

"Until the times of Peter, Moscow had been Asian - not only in its spirit, but also in its form. Peter did not change the spirit, but gave it European manners, culture and form. Everything that he saw in Europe and deemed applicable to a despotic state, he applied to Moscow and created the state which next to the possessive and slavish spirit of the Mongols, also has its polished forms; next to the spirit destroying the nation, it has the ability to manage the lack of freedom" ibid., p. 190).

"Moscow as the enemy of freedom is harmful to humankind and its progress. As a state which is slowly but constantly expanding its territory, it is dangerous to nations; as a state which supports all the European reactionary forces, it is dangerous to the civilisation" (ibid., p. 202). 
ments. Granted a pardon, he returned to Warsaw in October 1960." ${ }^{37} \mathrm{He}$ had no doubt that "the duty to work for one's country does not disappear in exile" and he wrote down and published his Siberian memoirs under the title Podróż więźnia etapami do Syberii w roku $1854 .^{38}$

Giller was the author of several important works on the theme of Siberia, at least some of which were partially known to Norwid: Groby polskie w Irkucku (Kraków 1864), Opisanie Zabajkalskiej krainy w Syberii (Leipzig 1867) and a collection of articles $Z$ wygnania (1870). ${ }^{39}$ In these accounts he hid his own suffering from the world, focusing instead on the tragic stories of other exiles. Mostly though, he provided his considerations of historiosophical and political nature. ${ }^{40}$ He was, undoubtedly, one of the most important sources of knowledge about the Russian reality for Norwid. The poet remained in close contact with him in the late 1860s and 1870s and benefited from the Stowarzyszenie Pomocy Naukowej [Scientific Assistance Society] founded by him in Paris. It is known that he read his annals from the January Uprising (Historia powstania narodu polskiego).

Another important Siberian exile with whom Norwid corresponded and exchanged opinionsduring the January Uprising was Karol Ruprecht (they probably met before Ruprecht's deportation, in Berlin in 1845). In a letter to Jule Michelet from October 1851, discussing Tsar Nicholas I's General and correctional penalties code which was in force "both in Poland and in Siberia," Norwid mentioned to the French historian and the advocate of the Polish cause (who was at that time working on Légendes democratiques du Nord, Paris 1854) the Siberian exile who

37 C. Norwid, List do J. Micheleta, [in:] IDEM, Dzieła wszystkie, Vol. X: Listy, ed. J. Rudnicka, Lublin 2008, pp. 354-355.

38 “Siostra moja, p. Paulina z Norwidów Suska, musiała sprzedać teraz wioskę (gdzie ja się urodziłem) jakiemuś panu Deskurowi, bratu tego, co był na Syberii - drobna szlachta albowiem nie wytrzymuje przemian socjalnych i wielkie tylko majątki utrzymują się w ręku tradycjonalnie. Dalej - edukacja dzieci wymagała zamieszkania w Warszawie" [My sister, Ms. Paulina Suska née Norwid, had to sell out the village (where I was born) to some Mr. Deskur, the brother of the one that was in Siberia - the lesser nobility does not survive social changes and only great properties remain with its owners in a traditional way. Furthermore - children's education requires moving to Warsaw] (List do Z. Krasińskiego [Letter to Z. Krasiński], PWsz, VIII, 356).

39 Cf. Andrzej Deskur. Sybirak i właściciel Sancygniowa. Homepage of the Deskur family: http://www.deskur.org/biogramy_0.htm [accessed: 29 August 2017]; M. NowAK, Działalność spoŁeczno-ekonomiczna Andrzeja Deskura, właściciela Sancygniowa, w drugiej połowie XIX wieku, "Studia Humanistyczno-Społeczne" 2009, Vol. 3, pp. 13-26.

40 M. Nowak, Działalność społeczno-ekonomiczna Andrzeja Deskura, p. 15; cf. also: M. Kukiel, Dzieje Polski porozbiorowej 1795-1921, Paris 1983, pp. 402-407; A. SzymaneK, Testament Andrzeja Deskura z 1846 roku. "Biuletyn Kwartalny Radomskiego Towarzystwa Naukowego" 32(1997), Vols. 1-2, p. 121. 
was sentenced to death for his participation in Mierosławski's insurgency and who, together with others, was granted a pardon at the gallows (16 March 1846):

...Karol Ruprecht, urodzony w województwie lubelskim, z rodziny pochodzenia niemieckiego - artysta architekt - protestant.

...Stefan Dobrycz, urodzony w Warszawie - syn kupca znanego od dawna w tym mieście z rodziny niegdyśs serbskiej-grekounita.

...Deskur, urodzony w swym majątku w Sandomierskiem, z rodziny pochodzenia francuskiego, lecz od wieków nobilitowanej w Polsce - katolik.

Spotkały się więc 3 różne stany i 3 religie. [...]

Zostali skazani na śmierć przez powieszenie i byli postawieni pod szubienicą wzniesioną na placu poza miastem.

Kiedy trzej księża przygotowali ich na śmierć, a kaci założyli im pętle na szyje, oficer w imieniu Cara ogłosił ułaskawienie; zaraz też nałożono im kajdany i zesłano na Sybir. ${ }^{41}$

...Karol Ruprecht, born in Lubelskie Voivodeship, in a family of German origin - an architectural artist - Protestant.

...Stefan Dobrycz, born in Warsaw - the son of a merchant well-known in this city - in a family of Serbian origin - Greek Catholic.

...Deskur, born in his land property in Sandomierz Region, in a family of French origin, but with a centuries-long history as Polish gentry - Catholic.

Three social classes and three religions met. [...]

They were all sentenced to death by hanging and brought to the gallows erected on a square outside the city.

When three priests were preparing them for death and executioners put loops on their necks, an officer granted them a pardon on behalf of the Tsar; they were immediately cuffed and deported to Siberia.

Stefan Dobrycz was serving his sentence in the Akatuy prison - a place for hardened criminals and felons. He managed to return to the country in the $1860 \mathrm{~s}$. The poet mentioned Andrzej Deskur in his letters to Zygmunt Krasiński (in October $1858^{42}$ ) and Teofil Lenartowicz (in January 1859) because Norwid's family

${ }^{41}$ Cf. http://jbc.bj.uj.edu.pl/dlibra/docmetadata?id=58182\&from=publication [accessed: 20 August 2017].

42 "Siostra moja, p. Paulina z Norwidów Suska, musiała sprzedać teraz wioskę (gdzie ja się urodziłem) jakiemuś panu Deskurowi, bratu tego, co był na Syberii - drobna szlachta albowiem nie wytrzymuje przemian socjalnych i wielkie tylko majątki utrzymują się w ręku tradycjonalnie. Dalej - edukacja dzieci wymagała zamieszkania w Warszawie" [My sister, Ms. Paulina Suska née Norwid, had to sell out the village (where I was born) to some Mr. Deskur, the brother of the one that was in Siberia - the lesser nobility does not survive social changes and only great properties remain with its owners in a traditional way. Furthermore - children's education requires moving to Warsaw] (List do Z. Krasińskiego [Letter to Z. Krasiński], PWsz, VIII, 356). 
property Laskowo-Głuchy was sold to Bronisław Deskur - "the brother of the one that was in Siberia" (Letter to T. Lenartowicz, PWsz VIII, 372-374).

Andrzej Deskur, like Norwid, graduated from a middle-school in Leszno in Warsaw. This future owner of Sancygniów in Świętokrzyskie Region was exiled to Siberia twice. "He was arrested in Ryczywól upon the Vistula (close to Kozienice) and detained under the accusation of preparing plans to overtake the Modlin fortress with Karol Ruprecht, Stefan Dobrycz and Mirski." ${ }^{44} \mathrm{He}$ spent the first 8 years of forced labour (as of 1846) in Akatuy close to Nerchinsk (like Dobrycz), and subsequently was sent up the Angara River to the Irkutsk Governorate. After the 1857 amnesty (after the Treaty of Paris), he was not allowed to return to the country as he was considered one of the main originators of the revolutionary movement. He was sent to Vyatka instead (we read in the Kraków daily "Czas" ["Time"] in 1857) where he was waiting to be granted a pardon until 1859 . Norwid could have learnt about his return to the country from "Wiadomości Polskie"["Polish News"] published in Paris on 1 January 1859."

During the January Uprising, Deskur became involved in political activity again:

According to his contemporaries, he was a man "of great learning and faith, big heart and love of his homeland for which he suffered a lot. [...] He did not hesitate to abandon everything for the sake of his homeland: his home, wealth, his beloved wife and two little children." During the uprising he was a civil head of Miechów District and a military organiser of Krakowskie Voivodeship. Captain Zygmunt Chmielewski's insurgent unit was formed in Iżykowice Forest belonging to Deskur. Andrzej Deskur served the role of a military organiser from 24 November 1863. In Ferbuary 1864, during a reconnaissance mission he conducted with colonel Krukowiecki, he was captured by Cossacks. After his arrest he was sentenced by court martial to be deported to Nerchinsk in eastern Siberia. Later, he was transported to Shadrinsk in Yekaterinburg Governorate. He remained in exile until $1867 .^{46}$

${ }^{43}$ Cf. Andrzej Deskur. Sybirak i właściciel Sancygniowa. Homepage of the Deskur family: http://www.deskur.org/biogramy_0.htm [accessed: 29 August 2017]; M. NowAK, Działalność społeczno-ekonomiczna Andrzeja Deskura, właściciela Sancygniowa, w drugiej połowie XIX wieku, "Studia Humanistyczno-Społeczne” 2009, Vol. 3, pp. 13-26.

${ }^{44}$ M. NowaK, Działalność społeczno-ekonomiczna Andrzeja Deskura, p. 15; cf. also: M. KuKIEL, Dzieje Polski porozbiorowej 1795-1921, Paris 1983, pp. 402-407; A. SzYManeK, Testament Andrzeja Deskura z 1846 roku. "Biuletyn Kwartalny Radomskiego Towarzystwa Naukowego" 32(1997), Vols. 1-2, p. 121.

${ }^{45}$ Cf. http://jbc.bj.uj.edu.pl/dlibra/docmetadata?id=58182\&from=publication [accessed: 20 August 2017].

46 M. Nowak, Działalność społeczno-ekonomiczna Andrzeja Deskura, pp. 16-17. 
He returned home only thanks to his family's efforts and the bribes they handed to Tsarist officials. ${ }^{47}$

Bronisław Zaleski was also deported (sent to Orenburg, almost at the verge of the "icy" Siberia)." ${ }^{48} \mathrm{He}$ was later a collaborator of Hôtel Lambert, secretary of Historical and Literary Society and head of the Polish Library in Paris. His sincere friendship, kindness, and help made the last painful days of life of Norwid - then the resident of the Ivry nursing home - more bearable. He shared with Norwid his memories from exile in the 1860 s and 1870 s and he probably also recommended to him the most recent literature on Siberia, for instance a little book about Tunka (PWsz, X, 55-57; 58-59, 59-61).

He had been imprisoned in Dorpat since 1838, and first deported to Czernigów from where he returned after three years. He was arrested again in Vilnius in 1847 for his contacts with a conspirator - Jan Roer. After two years in prison, he was sent to the Orenburg Corps (where he was promoted to the rank of officer in 1853). Subsequently he served in a battalion in Turinsk mines in the Ural Mountains. In his misery he was accompanied by Ludwik Turno and Taras Shevchenko. ${ }^{49}$ B. Zaleski spent nine years in total (1848-1856) in Orenburg, Khiva, and Turkestan. After his return to Europe, he settled in Paris (in 1863) and became friends with Norwid. Bronisław Zalewski was, by all means, an unusual exile:

[...] with his goodness and honesty, he was respected by the Poles serving in penal military units, as well as by the Russians. [...] He played [...] the role of a sort of a leader and moral role model for the Poles exiled not only to Orenburg, but to the whole Orenburg line. His name was widely known $[\ldots] .[\ldots]$

Because he was exceptionally kind and understanding of all human weakness, soon he became surrounded by an informal group of those who sought empathy and consolation. This remained the case for the rest of his life. Many people turned to him for advice and consolation even when he was in Paris. ${ }^{50}$

This apostle of love and reconciliation characterised by untainted nobility, always quiet, brave and reconciled with fate was perceived by his fellow exiles

47 Cf. Sancygniów, http://powstanie1863.zsi.kielce.pl/index.php?id=s03 [accessed: 20 August 2017].

48 Note that earlier there was also Tomasz Zan, who is mentioned in Bronisław Zaleski's accounts from Orenburg.

49 W. Caban, Z Orenburga do Paryża. Bronisław Zaleski 1820-1880, Kielce 2006, p. 53, $70,72-73$. Norwid himself was among those who sought the consolation of their own suffering in exile with Zaleski.

50 An excerpt from an anonymous letter quoted after: W. CABAn, Z Orenburga do Paryża, pp. 54-55. 
almost as a saint. An author of an anonymous letter preserved in his Siberian correspondence described him in words full of respect and admiration:

Bronisław Zaleski is one of the most beautiful and noblest people. He is maybe even unparalleled in that the ultimacy of bad fortune did not destroy the tranquillity of his heart, overshadow his beautiful spirit or break his moral fortitude, but above all, it did not snuff out the love which has been so strong within him so far. ${ }^{51}$

He never exposed his spiritual and physical suffering and never even liked writing about himself. ${ }^{52} \mathrm{He}$ had impressive scientific knowledge about Russia and Siberia; his numerous talents (especially for drawing) led to him being invited to participate in Russian research expeditions or to analyse materials obtained on such expeditions. Also, he was in charge of a library in Orenburg. ${ }^{53}$ Undoubtedly, the author of Vade-mecum heard many valuable details concerning the Romanov empire from him. Norwid was also the first to read B. Zaleski's extremely important publication Wygnańcy polscy w Orenburgu, ${ }^{54}$ which he got to know even before its printed publication in "Rocznik Towarzystwa Historyczno-Literackiego" ["Annals of the Historical and Literary Society"] in Paris in $1867 .{ }^{55}$ This keen interest in his exiled friend' ${ }^{56}$ accounts was understandable; only four of the numerous Oren-

$51 \quad$ Ibid., p. 19.

52 Ibid., pp. 53-63.

53 Cf. B. ZALESKi, Wygnańcy polscy w Orenburgu. "Rocznik Towarzystwa Historyczno-Literackiego w Paryżu za rok 1866,” Paris 1867, pp. 76-107.

54 B. Zaleski sent letters from Orenburg to Róża Sobańska (née Łubieńska), the "patroness of Siberia" known from many charitable acts, (asking for her care and prayers). He described in those letters the landscapes, climate, natural resources, flora and fauna of Russia, the life of the Kyrgyz and other peoples. They were published posthumously in "Przegląd Polski." Cf. Z Orenburga. Listy Bronistawa Zaleskiego za lata 1849-1856 podane przez Kalinkę. "Przegląd Polski" 60(1881), pp. 3-273. Sobańska, having learnt about Zaleski's drawing talent, sent him pencils and paper to Orenburg. It enabled the creation of the album of etchings titled Życie kirgiskich stepów published later in Paris.

55 Norwid informed Zaleski that he had read his book about exile in a letter from about 8 November 1866:

"Miły Bronisławie -

1. Czytałem o Orenburgu - wielce cenię Twoje prace w ogóle - poważam miarę i pokój w pisanych - talent i virtus w artystycznych cenić umiem." (PWsz, IX, 264).

[Dear Bronisław -

1. I read about Orenburg - I value your work in general - I respect your moderation and calm in your written works - I can also appreciate talent and virtus in artistic works.]

56 Cf. W. CABan, Z Orenburga do Paryża, pp. 13, 46. "Our history has been for many years going beyond the geographical borders of Poland. [...] a part of it, no less real, is the history of our 
burg exiles wrote down their accounts, and B. Zaleski's work stands out with its historical value and has been one of the primary sources of knowledge about the history of the Poles exiled into the Russian Empire. ${ }^{57}$ Its author was certain that the suffering of the Polish exiles greatly contributes to the process of civilising Russia and awakening the Russian conscience:

Considering $[\ldots]$ what our exiles, through their long-term suffering, have managed to do for themselves and for Poland's good name in general among the Russian society, how much conscience they have managed to awake there, [...] I cannot help but think that God's justice sent this unspeakable suffering for our ultimate purification and the awakening of the millions that are still asleep there. ${ }^{58}$

Norwid shared a similar reflection with Karol Ruprecht (in the year of the January Uprising):

[...] wszelaki Państwa Petersburskiego postęp [...] jest tylko zawsze koncesją jej monarchów, wydobytą NA NICHŻE SAMYCH I DLA NICHŻE SAMYCH PRZEZ KREW POLSKĄ!

[...] Polska jest dla Moskwy jakoby źródłem, które ona depce nogami, pijąc z niego. [...] bój jest przede wszystkim O TO TYLKO, tj. O DUCHA! (Letter to Karol Ruprecht, PWsz IX, 104).

exiles, whose letters are scattered throughout the whole Russian State. Without it, the big picture of our national life throughout the last one hundred years would not be complete; its significance is growing with the growing number of victims. Today, when this number is horrifyingly high, encompassing almost the whole generation, it is even more important to ponder over the fate of our past exiles [...]. If we wanted to make this picture more precise, we would have to include in it all the years of our misfortune, the whole Russia, and most importantly Siberia, Caucasus, and the Orenburg country, the three main places of exile. The secret archives of the $3^{\text {rd }}$ department of the Tsar's office may provide the materials for it, but now we have to rely on what is retained in individual memories.” B. ZALESKI, Wygnańcy polscy w Orenburgu, pp. 75-80.

57 Ibid., p. 107.

58 Cf. J. WiercińSKa, Przeoczone ogniwo. Rzecz o Antonim Zaleskim. "Biuletyn Historii Sztuki" 43(1981), Vol. 4, pp. 339-398. The author reconstructed the biography of the painter on the basis of, inter alia, Norwid's letters.

Antoni Zaleski is missing even from such valuable and comprehensive compendia as W. Śliwowska's dictionary (Zesłańcy polscy w imperium rosyjskim) or J. Trynkowski's compilation (Polski Sybir). A. Zaleski is not found in other publications such as: B. JĘDrYChOwska, Polscy zestańcy na Syberii 1830-1883, Wrocław 2000; L. Machnik, Fotografie powstańców styczniowych, Wrocław 2002; A. Brus, E. KACZYŃSKA, W. ŚLIwowsKA, Zestanie i katorga na Syberii w dziejach Polaków either. Antoni Zaleski's name appears only (on p. 408) in Księga Pamiątkowa opracowana staraniem Komitetu obywatelskiego w czterdziesta rocznice powstania roku 1863/1864 published in Lviv in 1904 by Józef Białynia Chołodecki, but refers not to Zaleski the painter, but to his 20 years younger namesake (born in 1842) who fought in Lewandowski’s, Michał Heydenreich's (nickname: Kruk) and priest Brzóska’s divisions. 
[...] any progress made by the Petersburg State [..] is only a concession made by its monarchs ON THEMSELVES AND FOR THEMSELVES THROUGH THE POLISH BLOOD!

[...] Poland is for Russia a kind of a spring from which it drinks treading it with its feet. $[\ldots]$ the fight is ONLY FOR IT, i.e. FOR THE SPIRIT!).

In Siberian biography dictionaries there is no mention of another post-January exile, Antoni Zaleski, ${ }^{59}$ who was Norwid's friend from Kokular's painting studio, a close companion from his Italian years, to whom the poet dedicated his work Bransoletka [Bracelet] and with whom he undertook some artistic endeavours. ${ }^{60}$ The bulk of this painter's artistic works has been lost, ${ }^{61}$ as well as the memory of the details of his exile to Vyatka (today's Kirov) in $1863 .{ }^{62} \mathrm{He}$ was deported there after an initial detention in the Vilnius citadel together with his 15-year-old (!) son Michał ("Michał shared the exile with me and returned when he was 20") 63 - his young daughter, Józefa, was taken care of by the family (the father did not see her for several years). Norwid mentioned Antoni's story in a letter to Konstanty Zaleski on the $25^{\text {th }}$ of January, 1864 :

Jesteśmy wszyscy jak po wielkiej burzy i oglądamy się nie doliczając [się ogó]łu. [...]

Wiem o Antonim i o synu jego, nie wiem, co z maleńką stało się. [...]

Teraz dzielić gorzkość samą jest zarówno powszednią i nieludzką rzeczą - tak dalece stało się ludzkim nieludzkie, a niepowszednie zwykłym (PWsz IX, 160-161).

59 Norwid made steel engravings of A. Zaleski's illustrations for Teofil Lenartowicz's Zachwycenie [Delight] and Btogostawiona [The Blessed]. Antoni was, in turn, a keen advocate of Norwid's writings. He persuaded him to publish a volume of collected poems. He was also "bombarded by the poet with pleas to distribute his writings (Rzecz o wolności stowa [On the Freedom of Speech]), to help sell his artistic works (Kościółek na Litwie [A Little Church in Lithuania]) or to send them to an exhibition (Kobieta chananejska [A Cannanean Woman]). As friends, for their whole lives they shared opinions about art and artistic exhibitions. Gomulicki supposed that A. Zaleski asked Norwid to send artistic correspondence from Paris to him. Norwid sent his biographical note to Kraków to A. Zaleski, for its inclusion in the dictionary of the Polish artists that the painter was preparing. Antoni Zaleski also managed the "packs" Norwid sent to Florence, when the poet was planning his trip to Italy (which eventually did not take place).

60 A. Zaleski illustrated, among others, Pani Twardowska [Mrs. Twardowska] (1863), Grażyna and Konrad Wallenrod (1864), Malczewski’s Maria (1867), Pan Tadeusz (published by Żupański, Poznań 1868).

61 “There is no information about Zaleski's time in Vyatka. He was certainly drawing, maybe even painting, but no works remained from that time. His friends were watching, from near and from afar, Antoni's tragic fate [...]." (Wiercińska, Przeoczone ogniwo, p. 375).

${ }^{62}$ A letter from Antoni Zaleski to Teofil Lenartowicz from 7 May 1868. Ms. The Polish Academy of Arts and Sciences (PAU) and the Polish Academy of Sciences (PAN), Scientific Library, Album Teofila Lenartowicza ,,Umarli żywi, ”' k. 4.

63 "Kurier Warszawski" gave information about his return to Warsaw on 2 December 1867. 
We are all as if after a great storm and we look around and cannot see the rest of us. [...] I know about Antoni and about his son, but I don't know what happened to the little girl. [...] Now to share bitterness is a thing that is just as common as inhumane - so much has the inhumane become humane and uncommon - common.

Antoni Zaleski was granted a pardon and returned to the country at the end of 1867. ${ }^{64}$ Norwid learnt about it from Bronisław Zaleski:

Od Ciebie doszła mię wiadomość o powrocie Antosia Zaleskiego - ode mnie - innym - do mnie zgłaszają się, gdzie? on - jaki adres probable?? - (PWsz IX, 309)

I learnt from you about the return of Antoś Zaleski - from me - others - come to me and ask, where? he - what address probable?? -

A. Zaleski's property was confiscated, his house (a mansion in Zubiszki) robbed and destroyed by Russian soldiers. It was, as he wrote from exile, "ciagle rabowanym i stanowiącym główną kwaterę wojenną, gdzie w salonie biwakowano" [constantly robbed and constituted the main military headquarters, the living room was a camp] (PWsz V, 368). ${ }^{65}$ Left with no financial means, the Tsarist exprisoner had to make a living to support his family by giving drawing and modern languages classes. ${ }^{66}$

The list of Norwid's Siberian contacts does not end with A. Zaleski. In 1872, the poet asked Prince Władysław Czartoryski to "find someone worthy" who

64 Apparently, Norwid contacted his exiled friend immediately, because soon afterwards, in December 1867 A. Zaleski sent a manuscript of Noc tysięczna druga [The Thousandth and Second Night] to Maria Faleńska; the manuscript that remained in the painter's house in Zubiszki throughout the uprising and the following years. "Nie wiem - pisał A. Zaleski - jakim cudem ocalał" [I don't know - wrote A. Zaleski - how on earth it survived] (PWsz V, 368).

65 Cf. J. WiercińsKa, Przeoczone ogniwo, p. 374.

66 Norwid wrote in a letter to Czartoryski about Anna's recent death (in 1872) and about her mother's situation: “(...) dla zdrowia pojechać musiała najprzód do Spa, potem do morza - gdzie przez Holandię jadąc (bez pasportu i pod przybranym, jak wielu w Emigracji, nazwiskiem) umarła. Dotąd szukamy przynajmniej grobu dla matki, która Azję i Europę, za córką jeżdżąc, sama osiemdziesięcioletnia, zwiedziła" [(..) for health reasons, she had to go first to Spa and then to the seaside - and when going through Holland (with no passport and under a false name, similarly to many in Exile) she died. We are still looking for a grave for a mother, who at the age of eighty, visited Asia and Europe while following her daughter" (PWsz IX, 520). This individual story of an abandoned old lady left with "no protection" became for Norwid a metaphor of the fate of the whole humiliated nation "b e z orłów, a mbasad i konsulów" [with no eagles, e mbassies, or consuls ] (PWsz IX, 521). 
would accompany "a deeply mournful" widow of a late November-Uprising insurgent (captain Mateusz Modzelewski) and a heroic mother - Weronika GłażewskaModzelewska on her journey to Warsaw. Her daughter and son were exiled, and she was brave enough to personally intervene with the Tsar for them. Disregarding her advanced age, she undertook a dangerous journey to Siberia in order to meet her children there:

Wielmożna pani Modzelewska, wdowa po wojowniku z 1830 r., który za wolność narodu walczył - osoba blisko osiemdziesięcioletnia (a która żadnej pieniężnej pomocy od nikogo nie potrzebuje), miała syna i córkę zesłanych na Syberię. Uważała przeto za rzecz serca macierzyńskiego pojechać do Petersburga, mówić z Monarchą Rosyjskim i uczyniła to. Że zaś mówienie monarchy tego żadnego dla osiemdziesięcioletniej wdowy nie spowodowało dobra, przeto uważała za słuszne pojechać na Sybir widzieć syna i córkę: i dopełniła tego. A skoro matka ze Syberii powróciła, córka tymczasem, będąc osobą arcyudarowaną, znalazła pomoc pokątną u zesłanych na Sybir uczonych rosyjskich, którzy dokonali tego, że córka pani Modzelewskiej do Paryża ujechała z wygnania swego. Syn tylko tej matrony pozostaje dotąd na Syberii.

Pani Modzelewska zastać przeto mogła i widzieć córkę swą w Paryżu, gdyby uzyskała ku temu pasport i znów sama nową odbyła podróż. Jakoż uczyniła i to jeszcze, jest w Paryżu.

Mieszka u artysty polskiego - pejzażysty, W-go Szermentowskiego, Batignolles, rue Truffaut N. 62, Paris (Letter to Wł. Czartoryskiego, PWsz IX, 520).

Honorable Mrs. Modzelewska, a widow of an 1830 combatant who fought for the freedom of the nation - an almost 80-year-old person (who needs no financial help from anybody), had a son and a daughter deported to Siberia. She felt in her heart that it was her maternal duty to go to Petersburg and speak with the Russian Monarch, and so she did. This conversation, however, did no good for the 80 -year-old widow, so she decided it would be the right thing to go to Siberia and see her son and her daughter, and so she did. When the mother returned from Siberia, the daughter, being a highly gifted person, found secret help with Russian scholars sent to Siberia and they managed to get Mrs. Modzelewska's daughter to Paris from exile. Only the son of this matriarch still remains in Siberia.

Mrs. Modzelewska could thus stay and see her daughter in Paris if she managed to get a passport and made the journey on her own again. She did even that and thus is in Paris.

She lives at a Polish artist - landscape painter's place, the Honourable Szermentowski, Batignolles, rue Truffaut N. 62, Paris.

This „highly gifted” Siberian exile mentioned by Norwid was Anna Modzelewska's daughter (hiding under the false name of Czaplicka), deported to Totma in Vologda Oblast (PWsz IX, 662). She was the partner of Pyotr Lavrov - Russian thinker, publicist, and revolutionary activist of "Narodnaya Volya" (deported to Vologda Governorate in relation to Karakozov's attempt at assassinating the Tzar). Norwid met both of them in Paris (cf. PWsz IX, 508-509). Anna Czaplicka fled from Siberia even before Lavrov did and made a living in the capital 
of France by running a haberdashery shop (or, as other sources inform, artificial flowers manufacture). The poet received a warm fur hat made "of a lamb from Crimea" as a gift from her. He expressed his thanks in poetry with mythological (Jason's quest for the "golden fleece") and evangelical (Christ as the sacrificial lamb) associations. They intertwine to create a reflection about the possibility of retaining Christian values ("wieniec z baranka" [a wreath of lamb") "w świecie, który klnie lub bałwochwali" [in a world that curses or worships idols] (PWsz II, 204). ${ }^{67}$

Aleksander Hercen - two times political exile (1834-1840, 1841-1842) - was another, apart from Lavrov, representative of the Russian revolutionary intelligentsia found among Norwid's friends and correspondents. ${ }^{68}$ The first sentence sent him to Perm upon the Kama River, near the Ural Mountains (and subsequently to Vyatka from which he managed to move after four years of exile to Vladimir on the Klyazma River). After the second trial, he was deported to Vyatka (changed to Novgorod). The grounds of his first arrest were „singing impudent songs" during one of the opposition group meetings (which, in fact, he did not even attend) and destroying Tsar Nicholas I's bust. Hercen was deported to Siberia for a second time for informing his father in a letter about a passer-by killed by a police officer in Petersburg. ${ }^{69}$

There were additional haphazard and accidental contacts with Siberia exiles or their parents in Norwid's life. For instance, in 1868 when he was giving a threeday lecture in Paris about "the masterpieces of every epoch" (asked to do so by Maria Bolewska), one of the Lithuanian "gals" who gave him her thanks at the end of the lectures was Aniela Witkiewiczówna (the sister of a would-be writer Stanisław Witkiewicz), whose parents and siblings were deported to Tobolsk for their participation in the uprising. ${ }^{70}$

${ }^{67}$ Cf. W. and R. Śliwowscy, Aleksander Hercen, Warszawa 1973.

68 Cf. N. ŁuBnICKI, Ewolucja światopoglądu Aleksandra Hercena, "Annales Universitatis Mariae Curie-Skłodowska, Lublin," Sectio F 1954, Vol. IX. Cf. also A. WALICKI, Dwa oblicza Hercena: filozofia wolności i ,,rosyjska idea." "Przegląd Filozoficzny," Nowa Seria 22(2013), Vol. 3(87), pp. 123-135.

${ }^{69}$ Cf. Z. Trojanowiczowa, E. LiJewska, Kalendarz życia i twórczości Cyprian Norwida, Vol. II, p. 349. Aniela's father - Ignacy Witkiewicz died in Siberia in the same year (1868).

70 Z. Trojanowiczowa, Sybir romantyków, p. 23. Until the November Uprising, the penal and penitentiary system of Congress Poland did not include deportation to Russia. To circumvent this fact, subjects were deported as citizens foreign to Congress Poland. After the November Uprising this obstacle was repealed. The Organic Status repealed the article about serving the sentence in the country. 
In 1875 , the poet was present (at least temporarily) at $2^{\text {nd }}$ International Geographical Congress organized by Société Geographique (PWsz X, 52). Aleksander Czekanowski, a former Siberian exile, prominent geologist and palaeontologist, was awarded a medal at this congress (prior to that he was awarded a gold medal of the Russian Geographical Society).

The reality of the "Paskevich Night" as well as that of emigration always put Norwid in closer contacts with Siberian exiles (mostly Polish, but also Russian). The number of such contacts is indicative of the huge number of Siberian deportation sentences (approximately 50 thousand Poles were deported after the November Uprising, ${ }^{71}$ and between 20 thousand to more than 100 thousand after the January Uprising ${ }^{72}$ and were ubiquitous throughout Polish reality at that time.

Norwid not only listened to the oral accounts of those who had returned, but also reached for Siberia-related publications, appearing since 1850s. Apart from Jakub Gordon's diaries and Agaton Giller's memoirs (Podróż więźnia etapami do Syberii w roku 1854) ${ }^{73}$ from 1860s, there was also Bronisław Zaleski's Wygnańcy polscy $w$ Orenburgu ${ }^{74}$ as well as (in the 1870s) Fr. Edward Nowakowski's book Wspomnienie o duchowieństwie polskim znajdujacym się na wygnaniu w Syberii, $w$ Tunce (Poznań 1875). Norwid most probably got this last publication from

71 Ibid., p. 34.

72 Cf. A. Giller, Podróż więźnia etapami do Syberii w roku 1854.

73 Cf. B. Zaleski, Wygnańcy polscy w Orenburgu.

74 "Tajemnica k r z y ż a n a r o d o w e g o w te trzy, mówię, promienie się rozpada:

Na emigrację na W schodzie: w kopalniach, Sybirze, posieleniu, gdzie ś w i ę t o ś c i ą jedynie się pracuje, tak jak i w przeżegnaniu na ramieniu prawym znak świętego kładziemy.

$\mathrm{Na}$ emigrację na $\mathrm{Z}$ a c h o d z i e [...].

$\mathrm{Na}$ emigrację narodową w $\mathrm{kraju}[\ldots]$.

Ramię czwarte jest złożone z tych, co już u O j c a sprawie służą. [...]

Tymczasem zaś krzy ż a mi e c z!...”

(Stowo zgody. List z emigracji

[The Word of Consent. A Letter From Emigration], 1851, PWsz VII, 44-45).

[The mystery of $\mathrm{th}$ e $\mathrm{n}$ a t i o $\mathrm{n}$ a $\mathrm{l}$ cros s is divided into these, I say, three beams:

The emigration in $\mathrm{t} h$ e $\mathrm{E}$ a s $\mathrm{t}$ : in mines, in Siberia, in forced settlement, where work is done through the holiness, just like when making the sign of the cross we place the sign of the holy spirit on the right arm.

The emigration in $\mathrm{th}$ e We s $\mathrm{t}[\ldots]$.

The national emigration in the country [...].

The fourth beam consists of these who serve the cause already with th e F a th e r. [...] In the meantime, not the cross, but h e s w ord!...] 
Bronisław Zaleski himself (or at least he recommended it to him), because he instantly wrote the following in a letter to him:

Odebrałem książkę o kapłanach w Syberii -

Czytałem p ołow e -albowiem w przysłanym egzemplarzu jest tylko połowa dwa razy przedrukowana - czy tak są wszystkie?...

Rad bym czytać c ałą i posiadać c a łą (Letter to Bronisław Zaleski, PWsz X, 55).

I received the book about the clergy in Siberia -

I've read half of it - because in the copy that I received there is only a half printed twice - are they all like that?...

I'd like to read the w h o le of it and have the w h o le of it.

The poet constantly reminded his compatriots about the place of the Polish Siberian exile in the national fabric and in the Polish exile in general. He considered Siberian exiles to be "emigration in the East" and one of the arms of the national cross; the cross which became "the gate," because the martyrdom of the exiles was an important constituent of "wszechprac i wszechzasług" [arch-works and arch-merits.${ }^{75}$ Norwid did not forget the exiles even when he was in America. Providing the exiles with state help and enabling them to return to the country was part of Norwid's project of state and social rules for the future of Poland, which he presented at a meeting of the Democratic Society of Polish Exiles in New York on 23 April, 1854. The gist of Norwid's speech is recapitulated in Section 4 of the minutes of that meeting:

Chcemy zatem Polski takiej, która by się dała postawić w kierunku dojścia [do] takiej, jakiej chcemy: $[\ldots]$

4. My w kwestii elementów składowych społecznych i moralnych wolnej hierarchii wyrabiania się, chcemy, ażeby z najpoważniejszej Emigracji naszej, to jest: z zesłanych na Sybir, z tych co w kopalniach są, żaden żywy duch nie był zapomniany i protekcją, choćby całą Rzeczpospolitą [...] na zgubę narażającą, [nie - R.G.-S.] osłoniony nie pozostał. [...]

Powyższymi punktami ob[ywatel] Norwid skreślit ducha Rządu Rzeczypospolitej Polskiej. ${ }^{76}$

75 After: Z. DAmbek, E. LiJewska, J. PiąteK-Swat, Amerykański ,,Skład zasad” Norwida?, "Tygodnik Powszechny" 2002, Vol. 32 of 11 August, p. 13.

76 "Wielu zginęło - wielu w Syberii? - i wielu ich pomni i modli się za nich?

Wielu gardło sobie brzytwą przerżnęło?

Wielu po heroicznych czynach, jak przyszło wytrzymać dwa miesiąca, poszło płaszczyć się w Ambasadzie Moskiewskiej??

Wielu 1 o kai? wielu $1 \mathrm{udz}$ i? wiele trupów?

Oto prakty c z ność - "

(Letter to M. Sokołowski, PWsz IX, 141). 
Thus, we want such a Poland that could be set into the direction of becoming the Poland that we want: $[\ldots]$

4. When it comes to social and moral constituent parts of our free self-determination, we want not a single living soul to be forgotten from those of our most severe Emigration, that is from those deported to Siberia, those who are in mines. Even if endangering the whole Republic [...] we want no one to be left without protection. [...]

With the abovementioned statements, citizen Norwid expressed the spirit of the Government of the Polish Republic.

He drew attention to the fate of the "Siberian exiles" also during a lecture about Juliusz Słowacki (PWsz VI, 443). He was trying to convince his listenersemigrants that without reading Anhelli "nie można być oświeconym patriotą polskim!" [one cannot be an enlightened Polish patriot!] (PWsz VI, 438):

Anhelli Juliusza jest to świecznik w mrokach sybirskich palący się, przeciwny zaś, a odpowiadający mu poemat jest Krasińskiego Wigilia Bożego Narodzenia: dwa poemata, bez których - śmiem powiedzieć rzecz, która się wyda napuszoną i dziwaczną, dlatego że ją powiem po prostu - bez których, mówię, przewodnictwa nie można być oświeconym patriotą polskim! (PWsz, VI, 438).

Juliusz's Anhelli is a candlelight burning in the Siberian darkness. Opposite is the corresponding Krasiński's poem Wigilia Bożego Narodzenia; these two poems without which, I dare say a thing that may come across as pompous and odd, because I say it directly - without the guidance of which, I say, one cannot be an enlightened Polish patriot!

Norwid remembered about the exiles to Siberia also in 1864, when the uprising started turning tragic. In his letter to Marian Sokołowski (who was "civil and political commissioner of the Russian territory" in the first months of the insurgency) in January 1846, he included a critical evaluation of the chaotic and mindless actions of the National Government. He wrote about the need to stop further senseless "sword duelling" for the sake of defensive politics which would result in minimizing losses and human tragedies, most importantly, though, in saving exiles:

[Many have died - many in Siberia? - and many remember and pray for them?

Many have slit their throats?

Many, after heroic deeds, when it came to resist for two months, have gone to cringe in the Moscow Embassy?

Many 1 a c k e y s ? many pe o p le ? many c or ps e s ?

This is practicality - ] 
[...] domyślono się, że trzeba wydawać i publikować listy ludzi narażonych na schwytanie, aby oszczędzić - a kiedyż się domyślą, że trzeba dziś tylko i tylko, i tylko odbijać na Sybir wywożonych i nic innego nie robić, bowiem strategii być nie może i nie ma [...] (Letter to K. Ruprecht, PWsz IX, 125).

[...] they realised that it is necessary to print and publish the lists of people in danger of being captured, in order to save them - but when will they realise that today it is only and only and only necessary to rescue those who are being deported to Siberia, and do nothing else, because there cannot be and there is no strategy $[\ldots]$.

He was asking to remember about and pray for those deported to Siberia in a letter to Sokołowski, in which - using rhetorical questions - he was making a tragic and "practical" balance of the dying uprising. ${ }^{77}$ Still mourning the loss of his brother Ksawery (in 1865), he shared the post-January national mourning with his compatriots. He expressed his deep sympathy for the "pain" of exiles and their families in a letter to Konstancja Górska:

Nieszczęście [...] dwakroć poczuwam, albowiem DOTĄD JESZCZE JESTEM POD NASTĘPSTWAMI bólu, który dotknął mię przez stratę brata, a zarazem jedynego człowieka, na którego spuścić się mogłem, i jedynego z moich normalnie postawionego.

I inni są albo na wygnaniu, albo mają bliższych ode mnie w Syberii! Sam tak będąc, dwakroć czuję boleść innych, jak ja postawionych (Letter to K. Górska, PWsz IX, 183).

I feel this misery [...] twice as hard, because I am still affected by the pain caused by the loss of my brother, the only person in whom I could confide and the only one of my people with the proper standing.

77 "Wielu zginęło - wielu w Syberii? - i wielu ich pomni i modli się za nich?

Wielu gardło sobie brzytwą przerżnęło?

Wielu po heroicznych czynach, jak przyszło wytrzymać dwa miesiąca, poszło płaszczyć się w Ambasadzie Moskiewskiej??

Wielu lokai? wielu ludzi? wiele trupów?

Oto praktyczność - "

(Letter to M. Sokołowski, PWsz IX, 141).

[Many have died - many in Siberia? - and many remember and pray for them?

Many have slit their throats?

Many, after heroic deeds, when it came to resist for two months, have gone to cringe in the Moscow Embassy?

Many lackeys? many people? many corpses?

This is practicality - ] 
Others are either in exile, or have their closer friends in Siberia! In my situation I feel the pain of other people, in a similar position, twice as hard.

He also saw the pressing need to document all individual tragedies. He mentioned it more than once, especially in his correspondence with former Siberian exiles: Karol Ruprecht and Bronisław Zaleski. One of Norwid's initiatives meant to pay tribute to "wszystkich pojedynczych wycierpień" [all individual sufferings] was the idea to found the Siberian society: ${ }^{78}$

[...] mówiłem był Karolowi (przed powstaniem syberyjskim), i mówiłem, i mawiałem: iż od lat parę należało było złożyć Towarzystwo en permanence Syberyjskie, gdzie by od morza B i a ł e g o d o C z a r n e go dośrodkowały się wszystkie pojedyncze wycierpienia i zdobycze, tworząc nieustanną całość ciągłych roczników jak Geograficzne Towarzystwo.

Ojczyzna robotę takową (lubo in partibus infidelium) uważać powinna jak departament kolonizacji lub coś podobnego - i departament, i komitet, i towarzystwo, i klub takowy istnieć i funkcjonować z dawien powinien!! - (Letter to Bronisław Zaleski, PWsz IX, 264-265).

[...] I told Karol (before the Siberian uprising), I told him and I said that an en permanence Siberian Society should have been founded many years ago. The place where all individual sufferings and achievements, from the White Sea to the Black Sea, would be centred, creating a never-ending continuation of annals, like the Geographical Society.

Such work (keenly in partibus infidelium) should be considered by our homeland as a department of colonisation or something like that - and a department, and a committee, and a society and also a club should have existed and be functioning a long time ago!!

In Norwid's dialogue $O$ historii [On History], created probably in 1851 (thus written before the post-January Siberian hecatomb as well as the publication of the first exiles' accounts from Siberia), there is a vital and unsettling question: how will the Polish historical thought (and the Polish collective consciousness) deal with the history of the nation written in "crosses?"; will these "hieroglify cierpienia" [hieroglyphs of suffering] be analysed by mature historiographers and interpreters? The poet had his doubts:

Co zaś - do dziejów Polski - jak się dzielą,

To bardzo łatwo skreślić: [...]

$[\ldots]$

78 As noticed by the authors of the Norwid's life chronicle, a similar initiative was undertaken by Władysław Broel-Plater who "in the defence of Catholicism persecuted in Poland and the priests deported to Siberia, created the international Oeuvre du Catholicism and Oeuvre d'assisstance des prêtres polonais exilés en Sibérie." Z. Trojanowiczowa, E. Lujewska, Kalendarz życia i twórczości Cypriana Norwida, Vol. II, p. 261. 
$[\ldots]$

Na ekspijację, którą naród umie,

Martyrologię też brzmiącą posępnie,

Co kilku ledwo znana oszczędzonym

Współ-uczestnikom, głow om-przewróconym (!)

(PWsz I, 165)

As it comes to how - the history of Poland - is divided,

It is very easy to sketch $[\ldots]$

$[\ldots]$

It is divided into expiation, which the nation knows,

Martyrology, which also sounds grave,

Which was spared only from a few

Co-participants, distorted heads (!)

Apparently, he was afraid that individual tragedies will become subject to soulless post mortem cataloguing, "inwentarz, / którego cel jest: śmierć - życie: komentarz" [an inventory, /the aim of which is: death - life: commentary] ( $O$ historii [On History], PWsz I, 163), that individual biographies will get deformed in sloppy press releases or will be blurred in unifying historian's descriptions devoid of thousands of names, that they will become commonplace to the public opinion:

- No - no - toć każdy wie o którymś przecie

Zasłanym w Sybir - w francuskiej gazecie

Pisują - wprawdzie przekręciwszy miana...

(PWsz I, 165).

- Well - well - everybody knows about someone

Deported to Siberia - in a French journal they

Write about them - misspelling their names, though...

He was offended by this imprecision in using data, distorting facts and names, progressing indifference and oblivion. ${ }^{79}$

79 As rightly emphasised by Łukasz Niewczas (Naród-analfabeta czyta księgę dziejów. Hermeneutyka przeszłości w wierszu ,O historii” Norwida, [in:] Norwid wobec historii, eds. E. Chlebowska, Ł. Niewczas, Lublin 2014, pp. 351-368), the author shows clear distance to some of the issues included in this dialogue about Polish historical consciousness, philosophy of history, and written history of the nation, which makes it rather ambiguous. It is full of truths expressed ironically, half-truths, incomplete truths, that is statements that are generally true, but entangled in error, platitude, and simplification - and reveals in this way, due to its ambivalence - an enormous complexity of the truth about Polish history, its approximativeness and high level of complication. Out of this polyphony it is possible, though, to extract seeds of "full truths," 
In the Polish narration about Siberia, there is a common analogy between tsarist Russia and murderous Rome. This analogy is found in the works of writers such as Zygmunt Krasiński (and even the very author of Quidam).$^{80}$ Bronisław Trentowski in his foreword to J. Gordon's Obrazki caryzmu wrote:

Indeed, our time is a h e r o i c t i m e, like the Greek Argonauts', a r e b e 11 i o u s t i m e, like in the Middle Ages, a b l o o d y t i m e, like at the beginning of Christianity. We have Roman catacombs, apostles' burnt offerings and much more: horrible knouts, mines, and exile. How many of our martyrs are already in their graves, how many suffer poverty showing bones

like, for instance, the reflection on the Polish (Christian) historiography included in the part elevating the Polish "cross-related" history:

[...] - Tacyt byłże już zrównany

Przez chrześcijańskie pióro?... z naszych krzyży

Zda się układać historia odmienna,

Mniej literacka może, lecz promienna!...

(PWsz I, 164)

[...] - Tacitus was already treated

With a Christian pen?... from our crosses

A different history seems to emerge,

Less literary, but more radiant!...

Tacitus, who described in his Annals even the cruellest crimes of Roman emperors in a concrete and fearless way (Norwid said about him that he "saw the decay" Notatki z mitologii [Notes from Mythology], PWsz, VII, 248), was considered by the Siberia exiles as a paragon of impartiality and chronicling competence. In the $19^{\text {th }}$ century it was commonly known that documenting the crimes committed by the tsars on the Polish people is a challenge for a modern, Christian chronicler similar to Tacitus:

"Why then the latter [Tacitus - R.G.-S.] has such a great influence on us? Through his works shines his self, his soul, his judgement. He gets into the root of all evil, affects the reader by exhaustively describing the tsarist cruelty, and them brings a word of consolation and finishes his lines with a painful and indignant exclamation. 'If there are no caring gods, then there are gods of revenge!' cries this honest pagan, exasperated with the sight of crime sitting on the throne and calls for the criminals to be punished" (J. GoRdon, Obrazki caryzmu, p. 211).

80 Cf. M. Karamucka, Upiorny Rzym Norwida, [in:] Od Syberii po Amerykę. Geografie wyobrażone polskich romantyków, eds. A. Kołos, T. Ewertowski, K. Szmid, Poznań 2013, pp. 47-56; M. KaRAMUCKA, Rzym i dziewiętnastowieczne mocarstwa imperialne (Rzym - Rosja; Rzym - Francja), [in:] IDEM, Antyczny Rzym Norwida, Poznań 2016, pp. 108-124. 
of their skeletons in misery and hunger! The time will come for the information about their lives to be searched for and for them to be seen as national Saints. ${ }^{81}$

This analogy, which Norwid essentially accepted, was mentioned in the dialogue $O$ historii [On History] for polemical reasons. This work, characterised by intellectual sophistication and insightfulness, criticises converting - even originally noble - ideas into a dangerous national stereotype, which can be used to justify false reasoning and encourage disastrous historical endeavours:

\section{[...]}

My - jak pierwotni czynim Chrześcijanie,

U których co dzień padał trup po trupie,

I nie pytano, co po nich zostanie,

Ale co w ciele było, tej skorupie -

Co odlatało na tęczowym skrzydle,

Wśród mąk, w zbliżonym niebios malowidle...

Więc wszyscy: - Brawo! brawo! tak, mój panie:

My - jak pierwotni czynim Chrześcijanie.

- Być może - Jerzy na to - rad bym jeno,

Ażeby fakcik mały poparł słowo,

Bo Chrześcijanie zgasłe pod hijeną,

Wyssane, mówię, ciała z zdartą głową

Nocami kradli i psalmy śpiewali,

Zapisywali, rylcem naznaczali, [...]

I stąd to onym skąpstwem krwi urosło

To ciało wieczne, ciało nieśmiertelne,

Które nad czasów moc bardzo się wzniosło,

Przez które żyjem co słońce Niedzielne!

(O historii [On History], PWsz I, 165-166)

$[\ldots]$

We do - as original Christians did,

Where dead body fell after dead body,

And no one asked what would remain of them,

But what was in the body, in this shell -

What flew away on a rainbow wing,

Among meadows, in a painting close to heavens...

Thus, all together - Bravo! bravo! yes, my lord:

We do - as original Christians did.

${ }^{81}$ B. Trentowski, $W$ miejsce przedmowy, p. XII. 
- Maybe - Jerzy says - I'd only like to

See a little fact support the word,

As Christians were robbing sucked corpses

Departed under the hyena, I say, with a head held high,

And singing psalms at night,

Making notes, marking with a stylus, $[\ldots]$

And hence with this penury of blood

Grew an eternal body, an immortal body,

Which raised above the might of the times,

Because of which we live every Sunday sun!

Norwid's attitude towards Christ's cross as well as the national crosses is wellknown. ${ }^{82}$ Deep, unwavering respect for this symbol (as well as for the national suffering), did not mean that the poet accepted equalling martyrdom with a senseless sacrifice and absurd glorification of bloodshed. He considered squandering human life as contrary to Christian values, which, from the beginning were characterised by "skąpstwo krwi" [sparing blood], striving to "uniepotrzebniania się

82 “" ...] Naród - pisał Norwid - jest to prosty człowiek. Czego się pługiem nie dogrzebie, nie domodli u krzyża i nie dopłacze w cichym łkaniu, to przetoczy się nad nim jak uczoność łacińska, jak protestantyzm lub doktryny encyklopedystów zeszłowiecznych.

[...] Bo kto, do Krzyża nawet idąc, minął krzyże ojczyste, ten p r z e b i e r a w męczeństwie! [...]

My nie mamy pla c u Męc z e n n i ków ani dotykalnego monumentu wielkiej naszej Ojczyzny, [...] ale [...] i Koloseum w starym Rzymie, krwią przesiąkłe męczeńską, nie wywołało mu pomników, jedno prosty krzyż z drzewa" (Głos niedawno do wychodźtwa polskiego przybyłego artysty [The voice of an artist recently joining the Polish emmigration], PWsz, VII, 7-9).

[...] The nation is a simple man. Whatever he will not dig out with a plough, whatever he will not pray for by the cross, whatever he will not cry for in his silent sobbing, it will pass him by like Latin wisdom, like Protestantism, like the doctrines of the encyclopaedists of the past century.

[...] Because the one who, even walking towards the Cross, left his national crosses behind, abounds in the martyrdom! [...]

We do not have the Martyrs' Square, or a palpable monument of our great Homeland, [...] but [...] even the Colosseum in the ancient Rome, soaked with martyrs' blood, did not evoke the erection of monuments, only a simple wooden cross" (Głos niedawno do wychodźtwa polskiego przybyłego artysty, PWsz, VII, 7-9).

Cf. also: B. LeszCzyńsKa, Tajemnica krzyża narodowego w pismach Cypriana Kamila Norwida, [in:] IDEM, Polski „Krzyż Dziejów” w twórczości wielkich romantyków, pp. 73-77, file:///C:/ Downloads/fulltext.pdf [accessed: 3 September 2017]. 
męczeństwa" [get rid of the need for martyrdom] through "wcielanie dobra" [embodying goodness] and "rozjaśnianie prawd" [enlightening the truth] (Promethidion. Epilog, PWsz III, 466). Martyrdom is, in fact, "broń największa" [the greatest weapon], but at the same time it is "ostateczna" [ultimate] - Norwid considered it appropriate to give such an explanation to his compatriots.

He saw other dangers too: spreading a(anti)historical attitudes which lead to a loss of the memory about the past ("Trzeba się wyzuć z przeszłości narowu!" [One has to get rid of the restlessness of the past]) as well as the temptation to underestimate and ignore martyrdom as a banal and over-familiar theme ("że wiedzieli / J uż o tym ws zyscy-rzec, jak gdyby wiedza/ Nie potępiała!" [that everybody knew/ About it already-to say it, as if the knowledge / Did not condemn one!]).

For the many reasons mentioned above, in his Parisian lectures on Słowacki, Norwid emphasised "pamięc serca" [the memory of the heart], known from chronicling as well as from literary visions of history:

Dopatrzono nareszcie, że we wszystkich semickich hieroglifach opuszczone są samogłoski, co już jest wielką zdobyczą; a kiedyż to dopatrzą, ile jest w historii opuszczonych łez, łkań, rozdarć, i tortur, które są powszednimi towarzyszami narodzenia się i wydobrzenia każdej prawdy? Jako więc królowa Jadwiga, kiedy dano jej wiedzieć o zapłaconej krzywdzie, pytała: „A k to ł z y z a pła c i ł?” - tak tedy pyta się dziś dusza Chrześcijanina, czytając historię tryumfalną (O Juliuszu Stowackim [On Juliusz Stowacki], PWsz VI, 447).

We know, at last, that vowels are omitted from the Semitic hieroglyphs - which itself is a great discovery, but when will it become known how many tears, cries, dilemmas, and tortures, which accompany the birth and maturation of all truth, are omitted from history? When Queen Jadwiga learnt about the redressed damage, she asked: "A nd who co mpen sat ed for the tears?" - this is a question that today is asked by a Christian soul reading the triumphant history.

Norwid himself was always aware of these tears unaccounted for in history, and he made scrupulous notes in his writings about every Siberia-related case which he came across.

Last but not least, it is worthwhile to ask a question about the poet's potential inspirations related to these written or oral Siberian accounts. There is no doubt that they left a mark in Norwid's artistic creations and his way of thinking about Russia; it is evidenced by the poems (Do Anny Czaplickiej [To Anna Czaplicka]) and «Ołówkiem» na ksiązeczce o Tunce ["In Pencil" on the Booklet on Tunka], which are direct literary fruits of these "Siberian" meetings and readings. By contrast, The rhapsody Niewola [Captivity], the dialogues Promethidion and O his- 
torii [On History] and the drawing Chata na Sybirze [The Hut in Siberia] (1855) prove that even as early as in the 1840s and 1850s (that is long before the publication of memoirs by Gordon, Giller and others) Norwid's historiosophical reflection - including Siberia - was keen, mature and exceptionally independent. It was shaped even earlier (as the author of the lecture on Słowacki said himself) by the strong influence of ground-breaking national works such as Dziady, Anhelli or Zygmunt Krasiński's Ostatni. ${ }^{83}$ The accounts from Siberia constituted a valuable source of the Parisian hermit's detailed knowledge about the exile reality. They influenced his thinking and writing about Siberia in the following years (Rzecz o wolności stowa [On the Freedom Speech]). Reflections on Russia included in Bronisław Zaleski's writings seem to be exceptionally close to Norwid's. This fact is not difficult to explain as Norwid was not only in good relations with this charismatic exile with a crystal soul, but also shared with him a certain spiritual similarity (most probably determining those relations) which was expressed in deep faith and religiosity, admirable nobility and integrity, magnanimousness and intellectual broad-mindedness. A combination of these virtues allowed both of them to interpret history in a way that went far beyond the bare historical facts, as well as to break irreconcilability and undertake constructive effort to convert the old "enemy" into a "tolerable neighbour."

\section{REFERENCES}

Brus A., KaczyŃsKa E., Ślıwowska W., Zestanie i katorga na Syberii w dziejach Polaków, Warszawa 1992.

Caban W., Z Orenburga do Paryża. Bronistaw Zaleski 1820-1880, Kielce 2006.

FieĆ́xo J., Rosja, Polska i misja zestańców. Syberyjska twórczość Agatona Gillera, Poznań 1997. Giller A., Podróż więźnia etapami po Syberii w roku 1854, Lipsk 1866.

GlaubicZ-SabiŃski J., Dziennik syberyjski. Dziewiętnaście lat wyrwanych z mojego życia, czyli dziennik mojej niewoli i wygnania od 1838 r. do 1857 r. włacznie, Vols. I-III, foreword and footnotes by J. Trynkowski, Warszawa 2009.

Gordon J., Moskwa: Pamiętniki J. G., Polaka z Korony, Obywatela Stanów Zjednoczonych Ame$r y k i$, Paryż 1861.

Gordon J., Obrazki caryzmu. Pamiętniki J. Gordona, Lipsk $1863^{2}$.

Gordon J., Sołdat, czyli sześć lat w Orenburgu i Uralsku: nowe pamiętniki J. Gordona, Bruksela-Lipsk 1864.

JanIK M., Dzieje Polaków na Syberii, Kraków 1928.

83 His poem Na Sybir [On the Siberian exile] written in 1845 also undertakes the Siberian theme. 
JęDrychowsKa B., Polscy zesłańcy na Syberii 1830-1883, Wrocław 2000.

KASPERSKi E., Wokól „Syberii” Norwida. Dwa modele etyki, historiozofii i patriotyzmu, [in:] Kresy, Syberia i literatura. Doświadczenie dialogu i uniwersalizmu, eds. E. Czaplejewicz, E. Kasperski, Warszawa 1995, pp. 153-172.

Librowicz Z., Polacy w Syberii, Wrocław 1993.

ŁAPIŃski Z., Norwid, Kraków 1984.

MACHNiK L., Fotografie powstańców styczniowych, Wrocław 2002.

Malinowska E., Rosja i Rosjanie we wspomnieniach Maksymiliana Jatowta, [in:] Od oświecenia ku romantyzmowi i dalej... Autorzy - dzieła - czytelnicy, esd. M. Piechota, J. Ryba, Katowice 2004, pp. 184-199.

Migration and Mobility in the Modern Age: Refugees, Travelers, and Traffickers in Europe and Eurasia, eds. A. Walke, J. Musekamp, N. Svobodny, Bloomington 2016.

NowaK M., Działalność społeczno-ekonomiczna Andrzeja Deskura, właściciela Sancygniowa, w drugiej połowie XIX wieku, „Studia Humanistyczno-Społeczne” 2009, Vol. 3, pp. 13-26.

Radomska M., Franciszek Dyonizy Cywiński - członek Spisku Braci Dalewskich w Wilnie i jego potomni, http://zeslaniec.pl/38/Radomska.pdf [accessed: 20.08.2017].

SKaliŃsKa E., ,,Dwie Syberie” - Norwid i Dostojewski o losach zesłańców polskich, [in:] IDEM, Norwid - Dostojewski Między diachronia a synchroniq odniesień, Warszawa 2012, pp. 247254.

ŚLIwOwska W., Zestańcy polscy w Imperium Rosyjskim w pierwszej połowie XIX wieku: stownik biograficzny, Warszawa 1998.

TORuŃ W., Norwid o niepodległej, Lublin 2013.

ToRuń W., Syberia w twórczości Cypriana Norwida, [in:] Zesłańcy postyczniowi w Imperium Rosyjskim. Studia dedykowane profesor Wiktorii Śliwowskiej, ed. E. Niebelski, Lublin-Warszawa 2008, pp. 373-384.

Trojanowiczowa Z., DambeK Z., Kalendarz życia i twórczości Cypriana Norwida, Vol. I: 1821 1860, Poznań 2007.

Trojanowiczowa Z., Lijewska E., Kalendarz życia i twórczości Cypriana Norwida, Vol. II: 1861-1883, Poznań 2007.

Trojanowiczowa Z., Sybir romantyków, Kraków 1992.

Trynkowski J., Polski Sybir. Zestańcy i ich życie. Narodziny mitu, ed. W. Śliwowska, Warszawa 2017.

Wiercińska J., Przeoczone ogniwo. Rzecz o Antonim Zaleskim, „Biuletyn Historii Sztuki” 43(1981), Vol. 4, pp. 339-398.

Wykaz szlachty w 1863 roku więzionej, prześladowanej i zesłanej z powiatu lidzkiego guberni wileńskiej, http://genealogia.lt/pdfs/Powstancy\%201863\%20r..pdf [accessed: 20.08.2017].

Z Orenburga. Listy Bronisława Zaleskiego za lata 1849-1856 podane przez Kalinkę. „Przegląd Polski” 60(1881), pp. 3-273.

ZALeSKi B., Wygnańcy polscy w Orenburgu, ,Rocznik Towarzystwa Historyczno-Literackiego w Paryżu za rok 1866," Paryż1867, pp. 76-107. 


\title{
NORWID AND THE EXILES TO SIBERIA
}

\author{
S u m m a r y
}

The exiles to Siberia had a profound influence on Norwid's way of thinking already in his middle school years (i.e. in the 1830s) as the next wave (following the one after the failure of the November Uprising) began at that time. The subject of exile and martyrdom was often discussed by Norwid in conversations and correspondence with his friends. Even among the poet's close and distant relatives, there were many people who were affected by the deportation to the East (Józef Hornowski, the Kleczkowski family, Konstanty Jarnowski). The list of Norwid's friends who were deported to Syberia is indeed very long: Karol Baliński, Maksymilian Jatowt (pseud. Jakub Gordon), Agaton Giller, Karol Ruprecht, Stefan Dobrycz, Andrzej Deskur, Bronisław Zaleski, Antoni and Michał Zaleski, Anna Modzelewska and her brother, Aleksander Hercen, Piotr Ławrow. There were also some occasional meetings with the exiled or their families (Aniela Witkiewiczówna, Aleksander Czekanowski). Norwid attentively listened to oral accounts of those who returned, he also read publications on Siberian themes published from the early 1950s (among others, by Giller, Gordon, B. Zaleski). In his speeches and letters he repeatedly drew attention to the necessity of commemorating the "Siberian exiles" and providing them with support - both spiritual and material - as well as establishing the Siberian Society, "where all single sufferings and conquest would come to balance." Providing the exiled with state protection and enabling their return to homeland became even one of the items of Norwid's project for the political and social principles of future Poland.

Key words: Norwid; Russia; Siberia; Sybiraks; the exiled; $19^{\text {th }}$-century exile literature.

Translated by Rafat Augustyn

Renata GadamsKa-Serafin - PhD, lecturer at the Faculty of Polish Studies of Jagiellonian University (Department of History of Romantic and Enlightenment Literature); e-mail: renata.gadamska@gmail.com. 